\title{
DAYA WARIS DAN HARAPAN KEMAJUAN SELEKSI KARAKTER AGRONOMI KEDELAI GENERASI F 2 HASIL PERSILANGAN ANTARA YELLOW BEAN DAN TAICHUNG
}

\author{
Maimun Barmawi, Andika Yushardi \& Nyimas Sa'diyah \\ Jurusan Agroteknologi, Fakultas Pertanian Universitas Lampung \\ Jl.Prof. Soemantri Brodjonegoro, No.1 Bandar Lampung 35145 \\ E-mail:nyimas_diyah@yahoo.com
}

\begin{abstract}
ABSTRAK
Penelitian ini bertujuan untuk mengetahui nilai duga daya waris (heritabilitas) dalam arti luas dan kemajuan seleksi pada populasi $\mathrm{F}_{2}$ hasil persilangan kedelai antara Yellow Bean dan Taichung. Daya waris dan kemajuan seleksi merupakan parameter genetik dalam proses seleksi. Penelitian ini telah dilakukan di Kebun Percobaan Universitas Lampung dari November 2011 sampai dengan Februari 2012 dan dilanjutkan di Laboratorium Benih dan Pemuliaan Tanaman. Penelitian ini menggunakan rancangan percobaan tanpa ulangan. Parameter genetik yang diduga adalah heritabilitas dalam arti luas dan kemajuan seleksi. Hasil penelitian menunjukkan bahwa populasi $\mathrm{F}_{2}$ mempunyai nilai duga heritabilitas dalam arti luas yang tinggi terdapat pada karakter umur berbunga, umur panen, tinggi tanaman, jumlah polong per tanaman dan bobot biji per tanaman, sedangkan pada karakter jumlah cabang produktif dan bobot 100 butir populasi $F_{2}$ mempunyai nilai duga heritabilitas dalam arti luas yang sedang. Nilai duga heritabilitas dalam arti luas yang tinggi menunjukkan bahwa suatu karakter lebih dikendalikan oleh faktor genetik daripada faktor lingkungan. Nilai duga kemajuan seleksi yang termasuk kategori rendah pada penelitian ini adalah umur berbunga, umur panen, jumlah cabang produktif, dan bobot 100 butir per tanaman, sedangkan nilai kemajuan seleksi yang tinggi terdapat pada karakter tinggi tanaman, jumlah polong per tanaman, dan bobot biji per tanaman. Nilai duga kemajuan genetik yang termasuk kategori rendah pada penelitian ini adalah umur panen, nilai kemajuan genetik yang termasuk kategori sedang terdapat pada umur berbunga dan bobot 100 butir, sedangkan nilai kemajuan genetik yang tinggi terdapat pada karakter tinggi tanaman, jumlah cabang produktif, jumlah polong per tanaman, dan bobot biji per tanaman. Tingginya nilai kemajuan genetik dalam suatu karakter mengindikasikan bahwa penampilan karakter tersebut didukung oleh faktor genetik, sehingga dapat melengkapi kemajuan seleksi.
\end{abstract}

Kata kunci : Daya waris, karakter agronomi, kemajuan seleksi, dan populasi $\mathrm{F}_{2}$

\section{PENDAHULUAN}

Kedelai merupakan sumber protein penting di Indonesia. Produksi kedelai di Indonesia tidak sebanding dengan konsumsi kedelai. Diperkirakan tiap tahun ratarata kebutuhan kedelai sebanyak 2,3 juta ton/tahun, sedangkan produksi kedelai dalam negeri hanya sekitar 800 ribu-900 ribu ton (Balai Penelitian Tanaman Kacangkacangan dan Umbi-Umbian, 2011). Produksi kedelai di Indonesia masih rendah sehingga harus ditutupi dengan impor. Harga kedelai lokal Indonesia terus meningkat sedangkan harga kedelai impor lebih murah. Pasar kedelai di Indonesia lebih dikuasai kedelai impor. Hal ini terjadi karena, kebijakan pemerintah yang membebaskan bea masuk impor kedelai untuk mengatasi kelangkaan kedelai akan merugikan petani lokal (Gatra, 2012).

Persilangan antar tetua yang memiliki perbedaan sifat merupakan salah satu langkah untuk perbaikan karakter suatu tanaman. Karena itu, dilakukan persilangan antara Yellow Bean dan Taichung, sehingga terjadi segregasi pada keturunan $\mathrm{F}_{2}$-nya. Akibat segregasi pada generasi $\mathrm{F}_{2}$ akan menghasilkan keragaman genetik yang luas.

Nilai duga heritabilitas arti luas dapat diduga dengan membandingkan besarnya ragam genetik total terhadap ragam fenotipik (Borojevic, 1990). Nilai heritabilitas yang tinggi menunjukkan bahwa faktor genetik lebih berperan dalam mengendalikan suatu sifat dibandingkan dengan faktor lingkungan (Knight, 1979; Poehlman, 1979). Heritabilitas (daya waris) menentukan kemajuan seleksi, makin besar nilai heritabilitas (daya waris) makin besar kemajuan seleksi yang didapatkan dan sebaliknya. Nilai duga kemajuan seleksi untuk menduga seberapa besar peningkatan yang akan diperoleh dari karakter yang diseleksi. Peningkatan akan dipengaruhi oleh intensitas seleksi yang ditetapkan, 
ragam suatu karakter, dan heritabilitas arti luasnya (Dahlan dan Slamet , 1992).

Besaran keragaman genetik dan heritabilitas bermanfaat untuk menduga kemajuan genetik yang didapat dari seleksi. Oleh karena itu, seleksi pada kedelai populasi $\mathrm{F}_{2}$ hasil persilangan Yellow Bean dan Taichung akan menunjukkan kemajuan genetik yang tinggi jika sifat yang dilibatkan dalam seleksi memiliki keragaman genetik dan nilai heritabilitas yang tinggi. Dengan demikian, diharapkan seleksi akan menghasilkan kemajuan genetik yang tinggi untuk beberapa karakter agronomi yang menjadi perhatian. Tujuan penelitian ini adalah untuk mengetahui nilai duga heritabilitas (daya waris) dalam arti luas dan kemajuan seleksi pada populasi $\mathrm{F}_{2}$ hasil persilangan kedelai antara Yellow Bean dan Taichung.

\section{METODE PENELITIAN}

Penelitian dilaksanakan di kebun percobaan Universitas Lampung dari bulan November 2011 sampai dengan Februari 2012. Benih yang digunakan adalah benih $\mathrm{F}_{2}$ Yellow Bean x Taichung. Penelitian ini dilakukan dengan rancangan percobaan tanpa ulangan karena benih yang digunakan adalah benih $\mathrm{F}_{2}$ yang masih mengalami segregasi (Baihaki, 2000). Analisis data yang dilakukan meliputi nilai duga heritabilitas arti luas dan kemajuan seleksi.

Nilai duga heritabilitas dalam arti luas diduga dengan menggunakan analisis komponen ragam dan dihitung berdasarkan rumus menurut Allard (1995) sebagai berikut:

$\mathrm{H}_{\mathrm{L}}=\frac{\sigma_{g}^{2}}{\sigma_{f}^{2}}$

$\sigma_{f}^{2}=\sigma_{g}^{2}+\sigma_{g}^{2}$

keterangan:

$\sigma_{f}^{2}=$ Ragam fenotipe

$\sigma_{g}^{2}=$ Ragam genetik

$\sigma_{\varepsilon}^{2}=$ Ragam lingkungan

Kriteria nilai heritabilitas dalam arti luas mengikuti Mc.Whirter (1979) dalam Masnenah dkk. (1997) dengan ketentuan sebagai berikut:

$\mathrm{H}<0,20 \quad=$ Heritablitas rendah

$0,20 \leq \mathrm{H} \geq 0,50 \quad=$ Heritabilitas sedang

$\mathrm{H}>0,50 \quad=$ Heritabilitas tinggi

Menurut Suharsono dkk. (2006), nilai duga kemajuan seleksi dapat dihitung berdasarkan rumus:

$$
\mathrm{R}=\mathrm{i}{ }_{x} \mathrm{H}_{\mathrm{L}}
$$

Keterangan:
$\mathrm{R}=$ Respons terhadap seleksi

$\mathrm{i}=$ Intensitas seleksi yang diterapkan

$\mathrm{H}=$ Pendergaan heritabilitas dalam arti luas suatu karakter

$\sigma_{\mathrm{x}}=$ Simpangan baku suatu karakter

$$
\mathrm{KG}=\frac{\mathrm{R}}{\text { Nilai tengah }} \times 100 \%
$$

Kriteria nilai duga kemajuan genetik berdasarkan Begun dan Sobhan (1991) dikutip Hadiati dkk. (2003) adalah

a. Tinggi apabila nilai $\mathrm{KG}>14 \%$;

b. Sedang apabila nilai $7 \% \leq \mathrm{KG} \geq 14 \%$

c. Rendah apabila $\mathrm{KG}<7 \%$

\section{HASIL DAN PEMBAHASAN}

Hasil penelitian ini menunjukkan bahwa nilai keragaman fenotipe dan genotipe yang luas terdapat pada karakter umur berbunga, umur panen, tinggi tanaman, jumlah polong per tanaman dan bobot biji per tanaman, sedangkan pada karakter jumlah cabang produktif dan bobot 100 butir menunjukkan nilai keragaman yang sempit (Tabel 1 dan 2). Untuk kisaran nilai tengah yang paling besar adalah tinggi tanaman, jumlah polong per tanaman dan bobot biji per tanaman (Tabel 3).

Seleksi akan efektif jika populasi memiliki keragaman genetik yang luas. Luasnya keragaman yang dihasilkan, baik keragaman fenotipe maupun genetik menunjukkan bahwa terdapat peluang besar untuk menyeleksi sifat-sifat yang diinginkan. Keragaman yang luas pada ragam genotipe dan fenotipe disebabkan oleh benih yang digunakan adalah benih $\mathrm{F}_{2}$ yang tingkat segregasinya tertinggi (Tabel 1 dan 2). Keragaman yang luas juga dapat terjadi karena kedua benih memiliki karakteristik genetik yang berbeda. Yellow Bean merupakan introduksi dari Amerika Serikat, sedangkan Taichung indroduksi dari Taiwan.

Kisaran nilai tengah suatu karakter akan menentukan luas tidaknya keragaman karakter tersebut. Semakin luas kisaran nilai tengah suatu karakter maka keragamannya semakin luas. Pada karakter tinggi tanaman, jumlah polong per tanaman dan bobot biji per tanaman memiliki kisaran nilai yang paling besar, sehingga keragaman pada karakter tersebut adalah luas (Tabel 3).

Nilai duga heritabilitas (daya waris) pada karakter umur berbunga, umur panen, tinggi tanaman, jumlah polong per tanaman, dan bobot biji per tanaman adalah tinggi, sedangkan pada karakter jumlah cabang produktif, dan bobot 100 butir menunjukkan nilai duga heritabilitas yang sedang (Tabel 4). 
Tabel 1. Nilai ragam fenotipe populasi $\mathrm{F}_{2}$ hasil persilangan Yellow Bean dan Taichung

\begin{tabular}{lcrrl}
\hline \multicolumn{1}{c}{ Peubah } & Ragam Fenotipe & Simpangan baku & \multirow{2}{*}{$\sigma_{f}^{2}$} & \multirow{2}{*}{ Kriteria } \\
& 17,94 & 4,24 & 8,47 & Luas \\
\hline Umur berbunga (hari) & 9,28 & 3,05 & 6,09 & Luas \\
Umur panen (hari) & 274,96 & 16,58 & 33,16 & Luas \\
Tinggi tanaman (cm) & 2,45 & 1,57 & 3,13 & Sempit \\
Jumlah cabang produktif (buah) & 2753,75 & 52,48 & 104,95 & Luas \\
Jumlah polong per tanaman (buah) & 165,98 & 12,88 & 25,77 & Luas \\
Bobot biji per tanaman(g) & 2,09 & 1,45 & 2,89 & Sempit \\
Bobot 100 butir(g) & & & \multicolumn{1}{c}{$\sigma_{\mathrm{f}}$} & \\
\hline
\end{tabular}

Keterangan: $\sigma_{f}^{2}>2 \sigma_{f}$ : luas, $\sigma_{f}^{2}<2 \sigma_{f}:$ sempit (Anderson dan Bancroft (1952) yang dikutip dalam Wahdah (1996)).

Tabel 2. Nilai ragam genotipe populasi $\mathrm{F}_{2}$ hasil persilangan Yellow Bean dan Taichung

\begin{tabular}{lrrrl}
\hline \multicolumn{1}{c}{ Peubah } & \multicolumn{1}{c}{$\sigma_{\mathrm{g}}^{2}$} & \multicolumn{1}{c}{$\sigma_{\mathrm{g}}$} & \multicolumn{1}{c}{$2 \sigma_{\mathrm{g}}$} & Kriteria \\
\hline Umur berbunga(hari) & 14,91 & 3,86 & 7,72 & Luas \\
Umur panen(hari) & 6,08 & 2,47 & 4,93 & Luas \\
Tinggi tanaman(cm) & 266,91 & 16,34 & 32,67 & Luas \\
Jumlah cabang produktif (buah) & 1,21 & 1,10 & 2,20 & Sempit \\
Jumlah polong per tanaman (buah) & 2718,43 & 52,14 & 104,28 & Luas \\
Bobot biji per tanaman(g) & 158,59 & 12,59 & 25,19 & Luas \\
Bobot 100 butir(g) & 0,98 & 0,99 & 1,98 & Sempit \\
\hline
\end{tabular}

Keterangan: $\sigma_{f}^{2}>2 \sigma_{f}$ : luas, $\sigma_{f}^{2}<2 \sigma_{f}$ : sempit (Anderson dan Bancroft (1952) yang dikutip dalam Wahdah (1996)).

Tabel 3. Nilai tengah dan simpangan baku genotipe $\mathrm{F}_{2}$

\begin{tabular}{lcc}
\hline \multicolumn{1}{c}{ Peubah } & Nilai tengah \pm simpangan baku & Kisaran Nilai Tengah \\
\hline Umur berbunga (hari) & $40,73 \pm 4,24$ & $36,49-44,96$ \\
Umur panen (hari) & $97,34 \pm 3,05$ & $94,29-100,38$ \\
Tinggi tanaman (cm) & $64,14 \pm 16,58$ & $47,56-80,72$ \\
Jumlah cabang produktif (buah) & $3,80 \pm 1,56$ & $2,24-5,37$ \\
Jumlah polong per tanaman (buah) & $104,31 \pm 52,48$ & $51,83-156,78$ \\
Bobot biji per tanaman (g) & $23,69 \pm 12,88$ & $10,81-36,58$ \\
Bobot 100 butir (g) & $12,04 \pm 1,45$ & $10,59-13,49$ \\
\hline
\end{tabular}

Tabel 4. Heritabilitas arti luas populasi $\mathrm{F}_{2}$ hasil persilangan Yellow Bean dan Taichung

\begin{tabular}{lcc}
\hline \multicolumn{1}{c}{ Peubah } & Heritabilitas $(\mathrm{H})$ & Kriteria \\
\hline Umur berbunga (hari) & 0,83 & Tinggi \\
Umur panen (hari) & 0,66 & Tinggi \\
Tinggi tanaman(cm) & 0,97 & Tinggi \\
Jumlah cabang produktif (buah) & 0,49 & Sedang \\
Jumlah polong per tanaman (buah) & 0,99 & Tinggi \\
Bobot biji per tanaman(g) & 0,96 & Tinggi \\
Bobot 100 butir(g) & 0,47 & Sedang \\
\hline
\end{tabular}


Nilai kemajuan genetik yang termasuk kategori tinggi terdapat pada tinggi tanaman, jumlah cabang produktif, jumlah polong per tanaman, dan bobot biji per tanaman. Nilai kemajuan genetik yang termasuk kategori sedang terdapat pada umur berbunga dan bobot 100 butir, sedangkan umur panen termasuk kategori rendah (Tabel 5).

Heritabilitas menentukan keberhasilan seleksi karena heritabilitas dapat memberikan petunjuk suatu sifat lebih dipengaruhi oleh faktor genetik atau faktor lingkungan. Nilai heritabilitas yang tinggi menunjukkan bahwa faktor genetik lebih berperan dalam mengendalikan suatu sifat dibandingkan dengan faktor lingkungannya.

Jumlah cabang produktif dan bobot 100 butir mempunyai nilai heritabilitas yang termasuk dalam kategori sedang. Untuk karakter umur berbunga, umur panen, tinggi tanaman, jumlah polong per tanaman, dan jumlah biji per tanaman termasuk kategori tinggi. Oleh sebab itu, karakter tersebut lebih banyak dikendalikan oleh faktor genetik dibandingkan dengan faktor lingkungan.

Seleksi terhadap karakter yang heritabilitasnya tinggi dapat dilakukan pada generasi awal. Sharma (1994) mengatakan bahwa suatu karakter yang memiliki nilai heritabilitas tinggi dapat diseleksi pada generasi awal $\left(\mathrm{F}_{2}\right.$ dan $\left.\mathrm{F}_{3}\right)$. Sebaliknya bila nilai heritabilitasnya rendah, maka karakter tersebut harus diseleksi pada generasi lanjut. Meskipun nilai heritabilitas untuk karakter umur berbunga, umur panen, tinggi tanaman, jumlah polong per tanaman, dan bobot biji per tanaman tinggi, perlu diperhatikan bahwa nilai heritabilitas tersebut dalam arti luas. Nilai heritabilitas dalam arti luas mencakup pengaruh aksi gen aditif, dominasi, dan epistasis. Jika yang lebih berperan dalam mengendalikan karakter yang bersangkutan adalah aksi gen dominans dan epistasis, maka seleksi tidak bisa dilakukan pada generasi awal. Jadi, harus diseleksi pada generasi lanjut.
Tingginya nilai kemajuan genetik dalam suatu karakter mengindikasikan bahwa penampilan karakter tersebut didukung oleh faktor genetik, sehingga dapat melengkapi kemajuan seleksi (Satoto dan Suprihatno, 1996). Karakter umur berbunga memiliki nilai kemajuan seleksi yang sedang dan memiliki heritabilitas yang tinggi sedangkan pada karakter bobot 100 butir memiliki nilai kemajuan seleksi dan heritabilitas yang sedang, hal ini diduga faktor genetik dan faktor lingkungan mempunyai pengaruh yang relatif sama besarnya.

Dari hasil penelitian ini menunjukkan bahwa karakter-karakter tinggi tanaman, bobot biji per tanaman dan jumlah polong per tanaman mempunyai nilai keragaman yang luas, nilai duga heritabilitas yang tinggi, dan nilai kemajuan genetik yang tinggi. Dengan demikian seleksi untuk memperoleh genotipe unggul dapat diterapkan pada karakter-karakter tersebut.

\section{KESIMPULAN}

Berdasarkan hasil penelitian dapat disimpulkan nilai duga heritabilitas (daya waris) tinggi terdapat pada karakter umur berbunga, umur panen, tinggi tanaman, jumlah polong per tanaman, dan jumlah biji per tanaman. Nilai duga heritabilitas sedang terdapat pada jumlah cabang produktif dan bobot 100 butir per tanaman. Nilai duga kemajuan seleksi yang tinggi terdapat pada karakter tinggi tanaman, jumlah cabang produktif, jumlah polong per tanaman, dan bobot biji per tanaman. Kemajuan seleksi sedang pada umur berbunga dan bobot 100 butir. Kemajuan seleksi rendah terdapat pada variabel umur panen.

\section{DAFTAR PUSTAKA}

Allard, R. W. 1995. Pemuliaan tanaman. Diterjemahkan oleh Manna. Diedit oleh Mulyani, M. Rineka Cipta. Jakarta. 366 hlm.

Tabel 5. Nilai kemajuan seleksi pada populasi persilangan $\mathrm{F}_{2}$ Yellow Bean dan Taichung

\begin{tabular}{lrrrl}
\hline \multicolumn{1}{c}{ Peubah } & Nilai tengah & \multicolumn{1}{c}{$\mathrm{R}$} & KG $(\%)$ & Kriteria \\
\hline Umur berbunga (hari) & 40,72 & 4,92 & 12,08 & Sedang \\
Umur panen (hari) & 97,33 & 2,81 & 2,89 & Rendah \\
Tinggi tanaman (cm) & 64,14 & 22,51 & 35,10 & Tinggi \\
Jumlah cabang produktif (buah) & 3,80 & 1,07 & 28,24 & Tinggi \\
Jumlah polong per tanaman (buah) & 104,30 & 72,73 & 69,72 & Tinggi \\
Bobot biji per tanaman (g) & 23,69 & 17,31 & 73,08 & Tinggi \\
Bobot 100 butir (g) & 12,04 & 0,95 & 7,91 & Sedang \\
\hline
\end{tabular}


Balai Penelitian Tanaman Kacang-kacangan dan Umbiumbian (Balitkabi). 2011. Varietas Unggul Kedelai.http://www.litbang.deptan.go.id/varietas/ $? \mathrm{l}=300 \& \mathrm{k}=310 \& \mathrm{n}=\& \mathrm{t}=\& \mathrm{sv}=[30$ Oktober 2011].

Baihaki, A. 2000. Teknik Rancang dan Analisis Penelitian Pemuliaan. Universitas padjajaran. Diktat mata kuliah. Bandung $91 \mathrm{hlm}$.

Borojevic, S. 1990. Principles and Methods of Plant Breeding. Elsevier Sci. Pub. Co. Inc. New York, $368 \mathrm{hlm}$.

Dahlan, M. dan S. Slamet. 1992. Pemuliaan tanaman jagung. Prosiding Simposium Pemuliaan I. Komda Jawa Timur. 17-38 hlm.

Gatra, S. 2012. Jaga Harga Kedelai di Kisaran Rp 7.000 Per kilogram. www.kompas.com. [9 September 2012].

Hadiati, S., Murdaningsih H. K., dan Rostini, N. 2003. Parameter Karakter Komponen buah pada Beberapa Aksesi Nanas. Zuriat 14 (2): 53-58.

Knight, R, 1979. Practical in Statistics and Quantitative Genetic. In R. Knight, (ed). A course manual in Plant Breeding. Australia. 214225.
Masnenah, E., Murdaningsih, Setiamihardja, R., Astika, W., dan Baihaki, A. 1997. Parameter Genetik Karakter Ketahanan Terhadap Penyakit Karat Kedelai Dan Beberapa Karakter Lainnya. Zuriat 8 (2) : 57-63.

Poehlman, J. M. 1979. Breeding Field Crop. AVI publishing Company Inc. Wetsport. Connecticut. $424 \mathrm{hlm}$.

Satoto dan B. Suprihatno. 1996. Keragaman genetik, heritabilitas dan kemajuan genetik beberapa sifat kuantitatif galur-galur padi sawah. Penelitian Pertanian Tanaman Pangan 15(1): 5-9.

Sharma, J. R. 1994. Principles and Practice of Plant Breeding. Tata McGraw-Hill Publishing Company Limited. New Delhi. 615 hlm.

Suharsono, M. Yusuf, dan A.P. Paserang. 2006. Analisis Ragam, Heritabilitas dan Pendugaan Kemajuan Seleksi Populasi F2 dari Persilangan Kedelai Kultivar Slamet x Nokonsawon. Tanaman Tropika 9 (2): 86-93.

Wahdah, R. 1996. Variabilitas dan Pewarisan Laju Akumulasi Bahan Kering Pada Biji Kedelai. Zuriat 7(2): 92-97. 